\title{
Is there any association between manganese level and schizophrenia? - a descriptive review
}

Czy istnieje związek między poziomem manganu a schizofrenią? - artykuł przeglądowy

\section{Dariusz Juchnowicz ${ }^{1}$ ABCDEF, https://orcid.org/0000-0003-2027-5469, Kaja Hanna Karakuła²} ABCDEF, https://orcid.org/0000-0003-1493-8502, Elżbieta Sitarz ${ }^{3}$ BEF, https://orcid.org/0000-0001-7503-1838, Alicja Forma ${ }^{4}$ BEF, https://orcid.org/0000-0001-8714-7627, Olga Padała ${ }^{3}$ BEF, https://orcid.org/00000003-1469-0877, Aleksander Janusz Ryczkowski5 ADE, https://orcid.org/0000-0003-2917-0030

${ }^{1}$ Department of Psychiatric Nursing, Medical University of Lublin, Poland

${ }^{2}$ Student Scientific Club at the I Department of Psychiatry, Psychotherapy, and Early Intervention, Medical University of Lublin, Poland

${ }^{3}$ I Department of Psychiatry, Psychotherapy, and Early Intervention, Medical University of Lublin, Poland ${ }^{4}$ Student Scientific Club at the Department of Forensic Medicine, Medical University of Lublin, Poland ${ }^{5}$ St. John of God Independent Public Provincial Hospital in Lublin, Poland

\begin{abstract}
Introduction: Manganese has a role in the membrane transport systems, synthesis of protein, vitamin C, and vitamins B, catalysis of hematopoiesis, regulation of the endocrine, immune system, blood sugar, reproduction, digestion, and blood coagulation. Furthermore, the level of manganese concentrations in human body appears to affect the occurrence of schizophrenia. The aim of this study was to search for relationships between the manganese level and the onset of schizophrenia.

Material and methods: A descriptive review was performed based on a literature search on Medline and Google scholar from 2003 to 2020, using keywords: schizophrenia, manganese, Mn. The included studies were meta-analyses, case-control studies, and cohort studies that examined differences in manganese concentrations in patients with schizophrenia and healthy controls. Result: Eight studies were selected for the review, with one reporting elevated levels of manganese, two showing no significant differences, and the rest including two meta-analyses stating lower manganese concentrations in patients with schizophrenia in comparison with controls.

Conclusion: In most of the researched studies, manganese concentrations in patients with schizophrenia were lower than in control groups, but not all of them reached the same conclusions. The relationship between manganese levels and schizophrenia must be further investigated.
\end{abstract}

Keywords: schizophrenia, manganese, Mn

\section{Streszczenie}

Wstęp: Mangan odgrywa ważną rolę w transporcie przez błony komórkowe, syntezie białka, witaminy C i witamin B, katalizie hematopoezy, regulacji układu hormonalnego, układu odpornościowego, poziomu cukru we krwi, układzie rozrodczym, trawieniu i krzepnięciu krwi. Ponadto wydaje się, że poziom manganu ma związek z występowaniem schizofrenii. Celem tego artykułu było poszukiwanie związków pomiędzy poziomem Mn a występowaniem schizofrenii.

Materiał i metoda: Przegląd literatury przeprowadzono na podstawie przeszukiwania artykułów w Medline i Google Scholar od 2003 do 2020 r., używając słów kluczy: schizofrenia; mangan; Mn. Uwzględniono badania, które obejmowały metaanalizy, badania kontrolowane i badania kohortowe, w których badano różnice stężeń manganu u pacjentów ze schizofrenią i zdrowych osób.

Wyniki: Do przeglądu wybrano osiem badań, z których jedno wykazało podwyższony poziom manganu, dwa nie wykazały istotnych zmian, a pozostałe wraz z dwoma metaanalizami stwierdziły obniżone stężenie manganu u pacjentów ze schizofrenią niż w grupie kontrolnej.

Wnioski: W większości analizowanych badań stężenia manganu u pacjentów ze schizofrenią były niższe niż w grupach 
kontrolnych, ale nie wszystkie z nich doszły do takich samych wniosków. Związek między poziomem manganu a schizofrenią musi być dalej badany.

Słowa kluczowe: schizofrenia, mangan, $\mathrm{Mn}$

\section{Introduction}

According to analyses of mammals' tissues, manganese $(\mathrm{Mn})$ is one of the most common microelements and its concentration ranges from 0.3 to $2.9 \mu \mathrm{g}$ per gram of wet tissue weight [1]. In humans, the normal blood Mn concentrations range from 4 to $15 \mu \mathrm{g} / \mathrm{L}$, 1-8 $\mu \mathrm{g} / \mathrm{L}$ in urine, and $0.4-0.85 \mu \mathrm{g} / \mathrm{L}$ in serum [2] but it is not clear if it can be a useful indicator of manganese status of tissue level [3]. Levels of Mn can be detected by analyzing the body fluids as well as hair samples [2]. Dietary Mn intake was established as $2.3 \mathrm{mg}$ per day for healthy adult men and as $1.8 \mathrm{mg}$ per day for healthy adult women increasing during pregnancy $(2.0 \mathrm{mg})$ and lactation (2.6 mg) [3]. Sources of Mn are dietary products such as whole grains, seafood, nuts, legumes, rice, leafy vegetables, coffee, tea, and others [4]. It is also found in pesticides and fungicides [5].

$\mathrm{Mn}$ is essential for human health. It is mainly absorbed through the gastrointestinal tract and after that it is accumulated in organs rich in mitochondria [6]. It has a role in the membrane transport systems, synthesis of protein, vitamin $\mathrm{C}$, and vitamin B, catalysis of hematopoiesis, regulation of the endocrine, immune system, blood sugar, reproduction, digestion, and blood coagulation $[7,8]$. $\mathrm{Mn}$ is also an important component of metalloproteins that take part in the metabolism of lipids - acetyl-CoA carboxylase, also in the metabolism of glucose and gluconeogenesis - phosphoenolpyruvate decarboxylase and pyruvate carboxylase, limits the synthesis of urea - arginase, contributes to maintaining bone health - glycosyltransferases [7]. But the most important are: Mn superoxide dismutase (MnSOD) which is a mitochondrial antioxidant (reducing oxidative stress) and glutamine synthetase (GS) that is critical for brain ammonia metabolism [6,7].

All macro- and microelements need to remain in a specific concentration range in order not to cause harm. In the literature, there are more cases of toxicity of Mn in excessive amount, especially neurotoxicity, rather than deficiency, which was mostly developed under experimental settings $[7,9]$. That is why there is no public concern to prevent Mn deficiency [3]. Drinking water can be polluted by this metal, leading to its high level of accumulation in body [6]. There is also another important way of Mn absorption, namely the inhalation of airborne Mn particles [6], which can result, for example, from combustion of an antiknock gasoline additive [5]. The first described overexposure of Mn was found in miners. They suffer from Parkinson's like neuromuscular condition and neurocognitive dysfunctions [10]. Toxic amount of Mn called manganism can also manifest itself by early psychotic symptoms [11]. Rats developed schizophrenialike behaviors after large administration of manganese chloride [12]. This is caused by the ability of Mn to produce free radicals and then, consequently, contribute to neurodegeneration [13]. On the other hand, lower levels of $\mathrm{Mn}$ in blood serum in humans result in impaired growth, skeletal defects, skin rashes, hair depigmentation, abnormal glucose tolerance. Mn deficiency can also change lipid and carbohydrate metabolism, altered mood, and increased premenstrual pain in women [3].

Most of $\mathrm{Mn}$ in the brain, up to $80 \%$ is located in glutamine synthetase [6]. Moreover, being responsible for controlling the metabolism of ammonia in the brain, GS has another key role [6]. Primarily it is found in astrocytes, where it converts the neurotransmitter glutamate (Glu) into glutamine (Gln). Next Gln is exported out of the cell where neurons can easily absorb it and reverse the change. Glu is an important neurotransmitter in the central neural system (CNS) where it can also be a precursor of another neurochemical transmitter: $\gamma$-Aminobutyric acid (GABA) [14]. However, excess extracellular Glu is neurotoxic [11]. It causes time-dependent damage even leading to cell death and generates reactive oxygen species (ROS) in different cell compartments [15]. This shows that GS has a neuroprotective effect and reduces neurodegeneration [7]. Lehmann et al. (2009) found that an increase in extracellular Glu enhances GS expression and inhibits glial Glu transporters [16]. Moreover, there is a negative correlation between a high level of $\mathrm{Mn}$ and reduced Gln uptake into astrocytes [11]. Also increase in $\mathrm{Mn}$ concentration lowers the activity of GS in the neural tissue of specific parts of the brain as the striatum and globus pallidus [17]. Additionally, animal models of schizophrenia show significantly decreased GS expression in superior temporal gyrus and cingulate cortex [18].

Another Mn-dependent enzyme is manganese superoxide dismutase, crucial in the prevention of mitochondrial oxidative stress through detoxification of reactive oxygen species $[8,9]$. MnSOD malfunctioning and diminished activity results in impaired neurotransmission, abnormal neuronal apoptosis and neurodegeneration [7]. Researches find it to be an important factor causing evolution of symptoms in schizophrenia [19]. It was observed that the activity of MnSOD increases after Mn supplementation [7,8] 
which leads to assumption that lower levels of $\mathrm{Mn}$ correlate with decrease enzyme functioning and onset of schizophrenia [20].

Knowledge about all functions of arginase is not complete, however, researches show that it can have a role in the neural-immune response, contributing to neuronal protection and regeneration [7]. Arginase's primary function is to convert arginine to ornithine in the urea cycle [7,21]. It can be found in the liver and other organs as in the kidneys, mammary glands, small intestine, and the brain where it is encoded by different genes, though it has some additional properties [14]. It may contribute to the regulation of nitric oxide production because nitric oxide synthase and arginase can inhibit each other through their interactions and metabolites [21]. Furthermore, they compete for the same substrate L-arginine [20]. Mn is crucial for catalytic activity and stability of arginase [14]. There are suggestions that Mn deficiency suppresses hepatic arginase activity [22] with animal models confirming this [14]. Also decreased concentration of $\mathrm{Mn}$ leads to the large production of nitric oxide (NO). NO can cause free radical-mediated neurotoxicity and can be found in high concentrations in patients with schizophrenia [20,21]. Consequently, researchers try to estimate to what extent manganese playsa role in the arginine-NO pathway and if it can be used in treatment [12].

\section{Material and methods}

A descriptive review was performed based on a literature search on Medline and Google scholar from 2003 to 2020. The following phrases were used as keywords: "schizophrenia", "manganese", "Mn". The included studies were meta-analyses, case-control studies, and cohort studies that examined differences in Mn concentrations in patients with schizophrenia and healthy controls.

\section{Results}

In recent years there have been more and more studies regarding the contribution of various metals to schizophrenia that have reported conflicting results about the concentration of $\mathrm{Mn}$ in patients [14,20,22-27]. Eight studies were taken under consideration, with one reporting elevated levels of $\mathrm{Mn}$ [23], two showing no significant difference $[22,25]$, and the rest stating that $\mathrm{Mn}$ concentration in patients with schizophrenia was lower than in controls $[14,20,22,26,27]$.

Liu et al. (2015) observed that higher concentrations of manganese $(>3.95 \mu \mathrm{g} / \mathrm{L})$ in serum were associated with an increased risk of schizophrenia (OR=19.269 (95\% CI: 1.436-258.626)) [23]. They, thereby, showed that $\mathrm{Mn}$ concentrations were approximately 4.6 times higher than a maximum allowable level according to the Agency for Toxic Substances and Disease Registry (ATSDR) U.S. Department of Health and Human Services [2].

In a study which analyzed selected trace metals taken from hair of schizophrenic patients, the concentration of $\mathrm{Mn}$ in this group remained unchanged compared to healthy controls [24]. Similar findings were noted by Nawaz et al. (2014). The authors did not find a difference in plasma Mn concentrations between controls and patients, except the newly diagnosed male patients who had elevated levels of Mn. However, this study has many limitations, e.g. lack of information about controls or addictions among chronic patients. Furthermore, the authors did not analyze the impact of different addictions on Mn levels on the newly diagnosed patients that could have altered the results [25]. Some studies suggest that Mn serum level can be increased by addiction to tobacco [28] or alcohol [29].

Yanik et al. (2003) showed a significant decrease in plasma concentration of $\mathrm{Mn}$ in schizophrenic patients compared to controls, as well as in levels of total nitrite and arginase. There were no differences in levels of Mn, total nitrite, and arginase between patients that use low and high doses of neuroleptics [14]. In 2004 Yanik et al. again noted the same pattern of Mn concentration, which was lower in patients than in controls [22]. Similar findings were reported by Cao et al. (2019) and Kaya et al. (2012) in serum and plasma samples, respectively. Cao et al. found the same significant decrease in $\mathrm{Mn}$ concentrations in all patient cases, first episodes and recurrent patients [20]. Additionally, Kaya et al. reported a positive correlation between decreased levels of $\mathrm{Mn}$ and $\mathrm{Mg}$ and a negative one between $\mathrm{Mn}$ and $\mathrm{Fe}$ [26]. Arinola et al. (2009) found a significant decrease in Mn concentrations in people suffering from schizophrenia on antipsychotic drugs in contrast to controls and newly diagnosed drug-free patients. However, the authors did not find differences between newly diagnosed drug-free patients and controls [27].

In 2019 Saghazadeh et al. prepared a large metaanalysis $(\mathrm{N}=1500)$ that included most of the mentioned above studies. They concluded that only in the subgroup where microelement levels were determined in plasma a significant decrease of Mn was observed in patients with schizophrenia in comparison to healthy controls, but not in the serum subgroup [12]. Additionally, the authors show that concentration of manganese in patients with chronic or previously diagnosed schizophrenia is lower than in controls [12]. In 2020 another meta-analysis was performed which included similar studies. The authors found that lower Mn concentrations were linked to schizophrenia and observed a positive correlation between the level of Mn and activity of two liver enzymes, namely MnSOD (Superoxide Dismutase) and hepatic arginase [30]. 


\section{Discussion}

So far, no firm conclusions on possible correlations between manganese levels and schizophrenia have been reached. While more studies claim that schizophrenia is connected with a lower concentration of $\mathrm{Mn}[14,20,22,26,27]$ and also meta-analyses have similar results $[12,30]$, some researchers observed no significant change $[22,25]$ and others reported elevated $\mathrm{Mn}$ in patients compared to controls [23]. This diversity of outcomes can be due to the heterogeneity of methodology of the studies. Firstly, researchers did not use similar selection criteria for patients and controls. Secondly, the studies were conducted in different locations. Distribution of manganese contaminated water and airborne Mn varies throughout regions and countries [31,32]. Evidence shows that inhalation of $\mathrm{Mn}$ is more toxic and causes stronger oxidative stress and neural apoptosis effect than ingestion $[6,10]$. Absorption of Mn through the lungs bypasses the liver's primary metabolism and directly affects the brain in animal models [33]. Study participants could be exposed to different amounts of Mn, which would alter the concentration and accumulation of Mn. There were no data about Mn intake and only one study included supplementation of microelements by participants as an exclusion criterion [23].

Moreover, the U.S. National Institute of Health indicates that it is not clear if measuring Mn concentrations in blood or serum can be a useful indicator of manganese status [3]. Similar reservations have also been expressed by some researchers [10]. Only in one study manganese concentration was determined by using participants' hair, and it did not show any correlation between Mn and prevalence of schizophrenia [24]. Mn accumulates in the brain region known as the basal ganglia, which can be detected by T1-weighted magnetic resonance that could be a better means to assess the long-lasting exposure of Mn [2].

Furthermore, a number of factors that can change the absorption and distribution of $\mathrm{Mn}$ in the human body should be considered in the above analyses, including intestinal $\mathrm{pH}$, the presence of the divalent metal transporter (DMT1), other metals competing for absorption [6]. For intake and export, Mn uses transporters that are not specific for this trace element. DMT1 is located in the gastrointestinal tract and brainblood barrier (BBB) where Mn competes with Fe for the binding site [8]. Research has shown that iron deficiency increases $\mathrm{Mn}$ absorption and accumulation in the brain, intensifying its toxicity [6-8,10]. Fe can also alter the hemostasis by binding to MnSOD instead of Mn, making it lose its antioxidant properties [7]. Additionally, Mn competes with zinc, calcium, and cation transporters that regulate the import and export of manganese through
BBB [5,34]. Also Kaya et al. observed a positive correlation between decreasing levels of $\mathrm{Mn}$ and $\mathrm{Mg}$ [26].

Concentration of $\mathrm{Mn}$ in blood serum is found by some researches to be enhanced by usage of tobacco [28] or alcohol [29] and reduced by antipsychotic medication [27,30]. Arinola et al. (2009) observed that patients on the antipsychotic drug had decreased Mn concentrations while drug-free patients did not differ in the Mn level with controls [27].

Other researches show no correlation between smoking, antipsychotic treatment, and Mn [20,22,24,35]. However, antipsychotic drugs could chelate $\mathrm{Mn}$, reducing its availability for stimulating enzyme activity [26,30]. In 2015 large meta-analyses were performed on 2522 participants which concluded that MnSOD significantly decreases in patients with schizophrenia [36]. According to Zhang et al., medication reduced blood SOD (also MnSOD) levels, and greater change in SOD was correlated with greater symptom improvement [37]. On the contrary, $\mathrm{Wu}$ et al. (2013) and Miljevic et al. (2018) observed significantly increased plasma SOD activities after patients' treatment $[38,39]$. Further, arginase activity or amount should be also altered by Mn. Yanik et al. (2003) did not note any differences in the level of Mn, total nitrite, and arginase levels between patients on low and high doses of neuroleptics [14]. Another study that analyzed post-mortem brains of patients with schizophrenia and healthy controls revealed that while arginase activity was not correlated with the concentration of antipsychotic drugs, it was positively correlated with the age of disease onset [40].

\section{Conclusion}

The issue of change in manganese levels in schizophrenic patients is still under discussion. No firm conclusions on possible correlations between manganese levels and schizophrenia have been reached so far. More studies report a decrease of manganese in patients with schizophrenia $[14,20,22,26,27]$ but there are some that show no change [22,25] or elevated Mn concentration [23]. Moreover, meta-analyses connected lower levels of manganese with schizophrenia [12,30]. Researchers do not know in what way $\mathrm{Mn}$ affects patients. It is also unclear how antipsychotic meditation influence $\mathrm{Mn}$ concentration. Inconstancy of studies results may also be caused by heterogeneity of compered groups, when taken under consideration: stage of disorder, taken medication, comorbidities, nicotine or alcohol consumption, and type of collected samples. Moreover, etiological heterogeneity of schizophrenia can play a key role in variability of authors outcomes. It is suggested that dysfunction of enzymes that are essential for brain health and for which $\mathrm{Mn}$ is a cofactor may contribute to 
this disorder $[12,20,21]$. However, the sample collection casts some doubt on the reliability of these findings, as measuring Mn concentrations in blood or serum can be a useful indicator of manganese status [3,10]. Further research is needed on $\mathrm{Mn}$ accumulation in the brain. Using T1-weighted magnetic resonance for the assessment could be one of the possible ways to bring more inside in this issue [2].

\section{Conflict of interest}

The authors have declared no conflict of interest.

\section{References}

1. Aschner JL, Aschner M. Nutritional aspects of manganese homeostasis. Mol Aspects Med. 2005;26(4-5):353-62.

2. Agency for Toxic Substances and Disease Registry. A Toxicological Profile for Manganese [Internet]. 2012 [cited 2020 Mar 22]. Available from: http://www.atsdr.cdc.gov/ toxprofiles/tp.asp?id=102\&tid=23

3. Manganese. Fact Sheet for Health Professionals. [Internet]. National Institutes of Health. 2020 [cited 2020 Mar 16]. Available from: https://ods.od.nih.gov/factsheets/ManganeseHealthProfessional/

4. Freeland-Graves J, Mousa T, Kim S. International variability in diet and requirements of manganese: causes and consequences. J Trace Elem Med Biol. 2016;38:24-32.

5. Chen P, Chakraborty S, Mukhopadhyay S, Lee E, Paoliello MMB, Bowman $\mathrm{AB}$, et al. Manganese homeostasis in the nervous system. J Neurochem. 2015;134(4):601-10.

6. Erikson KM, Aschner M. Manganese: its role in disease and health. Met Ions Life Sci. 2019;(19):253-66.

7. Horning KJ, Caito SW, Tipps KG, Bowman AB, Aschner M. Manganese is essential for neuronal health. Annu Rev Nutr. 2015;35:71-108.

8. Li L, Yang X. The essential element manganese, oxidative stress, and metabolic diseases: links and interactions. Oxid Med Cell Longev. 2018;2018:7580707-7580707.

9. Ye Q, Park JE, Gugnani K, Betharia S, Pino-Figueroa A, Kim J. Influence of iron metabolism on manganese transport and toxicity. Metallomics. 2017;9(8):1028-46.

10. Finley JW. Does environmental exposure to manganese pose a health risk to healthy adults. Nutr Rev. 2004;62(4):148-53.

11. Sidoryk-Wegrzynowicz M, Lee E, Albrecht J, Aschner M. Manganese disrupts astrocyte glutamine transporter expression and function. J Neurochem. 2009;110(3):822-30.

12. Saghazadeh A, Mahmoudi M, Shahrokhi S, Mojarrad M, Dastmardi M, Mirbeyk M, et al. Trace elements in schizophrenia: a systematic review and meta-analysis of 39 studies $(\mathrm{N}=5151$ participants). Nutr Rev. 2019;78(4):278-303.

13. Martinez-Finley E, Gavin C, Aschner M, Gunter T. Manganese neurotoxicity and the role of reactive oxygen species. Free Radic Biol Med. 2013;62:65-75.

14. Yanik M, Vural H, Kocyigit A, Tutkun H, Zoroglu S, Herken $\mathrm{H}$, et al. Is the arginine-nitric oxide pathway involved in the pathogenesis of schizophrenia? Neuropsychobiology. 2003;47:61-5.

15. Atlante A, Calissano P, Bobba A, Giannattasio S, Marra E, Passarella S. Glutamate neurotoxicity, oxidative stress and mitochondria. FEBS Letters. 2001 May 18;497(1):1-5.

16. Lehmann C, Bette S, Engele J. High extracellular glutamate modulates expression of glutamate transporters and glutamine synthetase in cultured astrocytes. Brain Res. 2009;(1297):1-8.

17. Morello M, Zatta P, Zambenedetti P, Martorana A, D'Angelo V, Melchiorri G, et al. Manganese intoxication decreases the expression of manganoproteins in the rat basal ganglia: an immunohistochemical study. Brain Res Bull. 2007;74(6):406-15.

18. Steffek AE, McCullumsmith RE, Haroutunian V, MeadorWoodruff JH. Cortical expression of glial fibrillary acidic protein and glutamine synthetase is decreased in schizophrenia. Schizophr Res. 2008; 103(1-3): 71-82.

19. Flatow J, Buckley P, Miller B. Meta-Analysis of Oxidative Stress in Schizophrenia. Biol Psychiatry, 2013;74(6):400-9.

20. Cao B, Yan L, Ma J, Min J, Park C, Nozari Y, et al. Comparison of serum essential trace metals between patients with schizophrenia and healthy controls. J Trace Elem Med Biol. 2019;51:79-85.

21. Yao J, Leonard S. Increased nitric oxide radicals in postmortem brain from patients with schizophrenia. Schizophr Bull. 2004;30:923-34.

22. Yanik M, Kocyigit A, Tutkun H, Vural H, Herken H. Plasma manganese, selenium, zinc, copper, and iron concentrations in patients with schizophrenia. Biol Trace Elem Res. 2004;98:10917.

23. Liu T, Lu Q-B, Yan L, Guo J, Feng F, Qiu J, et al. Comparative study on serum levels of 10 trace elements in schizophrenia. PLoS One. 2015;10(7):e0133622-e0133622.

24. Rahman MdA, Azad MAK, Hossain MdI, Qusar MMAS, Bari W, Begum F, et al. Zinc, manganese, calcium, copper, and cadmium level in scalp hair samples of schizophrenic patients. Biol Trace Elem Res. 2009;127(2):102-8.

25. Nawaz R, Zahir E, Siddiqui S, Usmani A, Shad KF. The role of trace metals and environmental factors in the onset and progression of schizophrenia in pakistani population. World J Neurosci. 2014;4:450-60.

26. Kaya B, Akdağ N, Fadillioğlu E, Taycan SE, Emre MH, Unal S, et al. Elements levels and glucose-6-phosphate dehydrogenase activity in blood of patients with schizophrenia. Dusunen Adam. 2012;25(3):198-205.

27. Arinola 0, Idonije O. Status of plasma nitric oxide and nonenzymatic antioxidants before and after antipsychotic treatment in Nigerian patients with schizophrenia. J Res Med Sci. 2009;14(1):37-42.

28. Rivera-Mancía S, Colin-Ramirez E, Montes S, Cartas R, VargasBarrón J, Vallejo M. Dyslipidemia and tobacco smoking synergistically increase serum manganese. Investigación clínica. 2017;58:238-49.

29. Grochowski C, Blicharska E, Baj J, Mierzwińska A, Brzozowska $\mathrm{K}$, Forma A, et al. Serum iron, magnesium, copper, and manganese levels in alcoholism: a systematic review. Molecules, 2019;24:1361.

30. Scassellati C, Bonvicini C, Benussi L, Ghidoni R, Squitti R. Neurodevelopmental disorders: metallomics studies for the identification of potential biomarkers associated to diagnosis and treatment. J Trace Elem Med Biol. 2020;(60):126499.

31. Frisbie SH, Mitchell EJ, Dustin H, Maynard DM, Sarkar B. World Health Organization discontinues its drinking-water guideline for manganese. Environ Health Perspect. 2012;120(6):775-8.

32. Dobson A, Erikson K, Aschner M. Manganese neurotoxicity. Ann N Y Acad Sci. 2004;1012:115-28.

33. Erikson KM, Dorman DC, Lash LH, Aschner M. Manganese Inhalation by Rhesus Monkeys is associated with brain regional changes in biomarkers of neurotoxicity. Toxicol Sci. 2007 Mar 7;97(2):459-66.

34. Peres TV, Schettinger MRC, Chen P, Carvalho F, Avila DS, Bowman AB, et al. Manganese-induced neurotoxicity: a review 
of its behavioral consequences and neuroprotective strategies. BMC Pharmacol Toxicol. 2016;17(1):57-57.

35. Firth J, Carney R, Stubbs B, Teasdale SB, Vancampfort D, Ward $\mathrm{PB}$, et al. Nutritional deficiencies and clinical correlates in firstepisode psychosis: a systematic review and meta-analysis. Schizophr Bull. 2017;44(6):1275-92.

36. Wang D-F, Cao B, Xu M-Y, Liu Y-Q, Yan L-L, Liu R, et al. MetaAnalyses of manganese superoxide dismutase activity, gene Ala9Val polymorphism, and the risk of schizophrenia. Medicine. 2015;94(36):e1507.

37. Zhang X, Zhou D, Shen Y, Zhang P, Zhang W, Liang J, et al. Effects of risperidone and haloperidol on superoxide dismutase and nitric oxide in schizophrenia. Neuropharmacology. 2012;62:1928-34.

38. Wu J, Kosten T, Zhang X. Free radicals, antioxidant defense systems, and schizophrenia. Prog Neuropsychopharmacol Biol Psychiatry, 2013;46:200-6.

39. Miljević ČD, Nikolić-Kokić A, Blagojević D, Milovanović M, Munjiza A,Marin M Jukić MM, et al. Association between soft neurological signs and antioxidant enzyme activity in schizophrenic patients. Psychiatry Res. 2018;269:746-52.
40. Liu P, Jing Y, Collie ND, Dean B, Bilkey DK, Zhang H. Altered brain arginine metabolism in schizophrenia. Transl Psychiatry, 2016;6(8):e871-e871.

\section{Corresponding author:}

Kaja Hanna Karakuła,

Student Scientific Club at the I Department of Psychiatry, Psychotherapy, and Early Intervention, Medical University of Lublin, Poland e-mail: kaja.karakula@gmail.com

Otrzymano: 15.06.2020

Zrecenzowano: 27.06 .2020

Przyjęto do druku: 10.07.2020 